\title{
Compensating Victims of Police-Fabricated Confessions
}

\author{
Mitchell P. Schwartz†
}

A fabricated confession is one of the most egregious instances of misconduct in the criminal justice system. When the police fabricate a confession, they are defrauding, misleading, and deceiving everyone involved in the criminal process, consequently violating the criminal defendant's constitutional rights. Procedural safeguards, such as standards for admitting confessions into evidence and the exclusionary rule, do not sufficiently deter police-fabricated confessions, and provide no compensation to victims of such misconduct.

Although excluding the fruits of illegal searches and interrogations deters police from some kinds of misconduct, the system falters when police fabricate confessions. A fabricated confession itself is inadmissible even without the exclusionary rule because it cannot be authenticated. And since the police-fabricated confession is by definition made up, there is no other evidence discovered and hence no evidence excluded. Finally, because no evidence is excluded, there is little deterrence: In cases when the police try to use fabricated confessions, they don't lose anything if they are caught, and consequently may attempt to fool the judicial system again in the future.

Just as the exclusionary rule provides little deterrence to policefabricated confessions, it provides no compensation to the innocent victims of such misconduct. Section 1983 of the Civil Rights Act, however, may be used to provide such relief, thereby deterring police from fabricating confessions.

In order to raise a Section 1983 claim, a harmed party must establish that a state official acting under color of state law violated his federal or constitutional rights. Although police violate no federal right simply by fabricating a confession, once that fabricated confession is used in a criminal proceeding, numerous constitutional rights could be implicated. Depending on the stage of the criminal process in which the fabricated confession is used, a suspect may suffer harms such as false arrest, imprisonment, indictment, or an unfair trial. These are harms that Section 1983 suits can and should remedy.

$\dagger$ B.S. 1998, Northwestern University; J.D. 2003, The University of Chicago. 
In this Comment, I argue that since confessions are among the most, if not the most, prejudicial pieces of evidence presented at criminal trials, in order to deter police and compensate victims of police-fabricated confessions under Section 1983, courts should apply a but-for causation rule similar to the exclusionary rule. Just as courts use the exclusionary rule to exclude all derivative evidence through the "fruit of the poisonous tree" doctrine, courts should use the proposed "poison from the poisonous tree" doctrine to trace all of the harms that stem from the use of a fabricated confession in analyzing the Section 1983 claim; not just those harms that are shown to have been foreseeable or direct consequences of the use of that confession. The courts that have addressed these Section 1983 claims have not directly applied but-for causation. However, this is the theory by which the cases can be reconciled.

In Part I of this Comment, I discuss the weight afforded to confessions in the criminal process, standards of confession admissibility, and the exclusionary rule. In Part II, I address the requirements for bringing Section 1983 claims, and the immunities afforded officials. In Part III, I lay out the "poisons" doctrine, and argue for a but-for causation standard in Section 1983 claims for police-fabricated confessions.

\section{ADMISSIBILITY OF CONFESSIONS}

\section{A. Confessions Are among the Most Damaging Forms of Evidence}

Manufacturing fabricated evidence to use in a criminal proceeding is a "gravely serious wrong." Fabricating a confession has an even greater potential for harm, due to a confession's impact on juries and the criminal process as a whole. The Supreme Court first described the impact of confessions on the criminal process in 1884, when it stated that "a deliberate, voluntary confession of guilt is among the most effectual proofs in the law, and constitutes the strongest evidence against the party making it." ${ }^{2}$ Commentators have stated that a confession is the most influential evidence and is in effect a guilty plea, ${ }^{3}$ turning the presumption of innocence into a presumption of guilt. ${ }^{4}$

\footnotetext{
1 Devereaux v Abbey, 263 F3d 1070, 1083 (9th Cir 2001) (Kleinfeld dissenting).

2 Hopt $v$ Utah, 110 US 574, 584-85 (1884). See also Simon Greenleaf, $A$ Treatise on the Law of Evidence $\$ 215$ at 299-300 (Little, Brown 11th ed 1863).

3 See Lawrence S. Wrightsman and Saul M. Kassin, Confessions in the Courtroom 1 (Sage Publications 1993); Charles E. Torcia, 4 Wharton's Criminal Evidence $\$ 624$ at 14 (Lawyers Cooperative 14th ed 1987).

4 See Charles J. Ogletree, Are Confessions Really Good for the Soul?: A Proposal to Mirandize Miranda, 100 Harv L Rev 1826, 1844-45 (1987) ("Once a suspect confesses ... to police, the subsequent trial is often merely a formality; the suspect bears the almost impossible burden of countering the statement and establishing her innocence."). See also Richard A. Leo,
} 
Justice White called a confession the most damaging form of evidence, noting that "[e]ven the testimony of an eyewitness may be less reliable than the defendant's own confession."

Studies have demonstrated that jurors consider confessions to be the most persuasive evidence of a defendant's guilt. ${ }^{6}$ In one study, mock jurors were given either: (1) circumstantial evidence; (2) eyewitness testimony from either a stranger or acquaintance; or (3) testimony that the accused had confessed to the police. The subjects who received the confession were significantly more likely to view the defendant as guilty than those who received the other evidence. ${ }^{8}$ As a result, some have argued that the weight afforded confessions turns an entire criminal proceeding into a matter of form instead of substance, rendering the trial essentially extraneous. ${ }^{10}$ Thus the risk that a fabricated confession might get to a jury - and that they might convict because of it-must be averted. However, the harms do not stop here: A fabricated confession can affect the manner in which the criminal process proceeds from the start.

The entire criminal process takes on a different form if the police are able to secure a confession. " Even if it is not needed to establish probable cause to charge a suspect initially, a confession will greatly strengthen the prosecution's case. ${ }^{12}$ As a result, prosecutors will almost always agree to prosecute a case if the police can produce a confession. ${ }^{13}$ Thus, in addition to making a guilty verdict much more likely, a fabricated confession can increase the chances that a defendant will be wrongly arrested, indicted, and tried in the first place.

Police Interrogation and Social Control, 3 Soc \& Legal Stud 93, 99 (1994) ("If someone confesses, no one has any doubt that the suspect is guilty.").

5 Bruton v United States, 391 US 123, 140 (1968) (White dissenting).

6 See Welsh S. White, False Confessions and the Constitution: Safeguards Against Untrustworthy Confessions, 32 Harv CR-CL L Rev 105, 134 (1997) (citing empirical data showing that jurors do not believe that anyone would confess unless they actually committed the crime); Leo, 3 Soc \& Legal Stud at 99 (cited in note 4) ("[J]uror studies and mock jury experiments have found that confessions are considered more dispositive of a defendant's guilt than any other form of evidence.").

7 Gerald R. Miller and F. Joseph Boster, Three Images of the Trial: Their Implications for Psychological Research, in Bruce Dennis Sales, ed, Psychology in the Legal Process 19, 20-21 (Spectrum 1977).

8 See id.

9 See Richard A. Leo, Criminal Law: Inside the Interrogation Room, 86 J Crim L \& Criminol 266, 298-99 (1996) (finding that confessions have such a significant effect on every step of the criminal justice process that "once a suspect confesses to police his case is largely over").

10 See Wrightsman and Kassin, Confessions in the Courtroom at 2 (cited in note 3).

11 See Leo, 3 Soc \& Legal Stud at 99 (cited in note 4) (reporting a conversation with a police officer who stated "that there is nothing comparable to getting a confession because it puts a case on an entirely different track").

12 See White, 32 Harv CR-CL L Rev at 136 (cited in note 6).

13 See Leo, 3 Soc \& Legal Stud at 99 (cited in note 4). 


\section{B. Admissibility Standards for Confessions}

Since confessions may be so harmful, courts examine confessions with great scrutiny before admitting them into evidence. The admissibility requirements for confessions help to ensure that a fabricated confession will not be used at a trial to convict a criminal defendant. Due process requires that a confession be voluntary. ${ }^{14}$ Involuntary, coerced, false, and fabricated confessions are not admitted into evidence because they offend fundamental principles of criminal procedure..$^{15}$

To prevent the admission of such evidence, confessions are examined from two perspectives: the voluntariness of the accused in confessing, ${ }^{16}$ and the actions undertaken by law enforcement officials to obtain the confession. ${ }^{17}$ Historically, confessions that have been held to be inadmissible within this framework include those induced by violence or fear, or promises to confer benefits upon the accused.

Thus, these procedural safeguards are meant to protect a victim of an improper confession from conviction. These safeguards are used not "to shield the wicked," but to protect the innocent..$^{19}$ For the innocent victims, however, this may be too little, too late. Admissibility

14 See Brown v Mississippi, 297 US 278, 286-87 (1936).

15 See Rogers $v$ Richmond, 365 US 534, 541 (1961) ("[T]he methods used to extract [such confessions] offend an underlying principle in the enforcement of our criminal law: that ours is an accusatorial and not an inquisitorial system."). See also Spano v New York, 360 US 315, 32021 (1959):

The abhorrence of society to the use of involuntary confessions does not turn alone on their inherent untrustworthiness. It also turns on the deep-rooted feeling that the police must obey the law while enforcing the law; that in the end life and liberty can be as much endangered from illegal methods used to convict those thought to be criminals as from the actual criminals themselves.

16 See, for example, Hopt, 110 US at 584 ("A confession, if freely and voluntarily made, is evidence of the most satisfactory character.").

17 See, for example, Lego v Twomey, 404 US 477, 485 (1972) ("The use of coerced confessions, whether true or false, is forbidden because the method used to extract them offends constitutional principles.").

18 See Brown, 297 US at 284, 287 (reversing a conviction based in part on a confession coerced by whipping); Bram $v$ United States, 168 US 532, 561-63 (1897) (holding a confession inadmissible where the accused was forced to remove his clothes during an interrogation, and made to believe that his silence would implicate him); Sorenson v United States, 143 F 820, 824 (8th Cir 1906) (reversing a conviction because the confession was obtained after the accused was told that the matter would be "overlooked in state court," which was an unlawful promise of benefits). Use of deception or trickery, though frowned upon, has been admitted as long as it did not produce a false confession. See United States v Moreno-Flores, 461 F2d 1001, 1002 (9th Cir 1972).

19 Arthur E. Sutherland, Jr., Crime and Confession, 79 Harv L Rev 21, 22-23 (1965). Although guilty defendants may benefit from these protections, it is "less evil that some criminals should escape than that the Government should play an ignoble part." Id, quoting Olmstead v United States, 277 US 438, 470 (1928) (Holmes dissenting). 
standards do nothing to protect the defendant from harms other than conviction.

\section{The Exclusionary Rule}

The exclusionary rule, like the admissibility standard, is meant to keep improper evidence out of the courts. However, it is designed to work earlier in the process. By weakening the prosecution's case, the exclusionary rule is meant to deter police from improperly obtaining evidence. It requires the exclusion of evidence directly obtained by improper means, as well as any derivative evidence-referred to as the "fruit of the poisonous tree." doctrine I propose complements the exclusionary rule.

The exclusionary rule dictates that any wrongfully obtained evidence cannot be used in a criminal proceeding against the victim of the wrongful conduct. ${ }^{21}$ The rule affects: (1) illegal searches and seizures; (2) illegally obtained confessions; (3) illegally secured identification testimony such as improper line-ups; and (4) evidence obtained through other police methods that "shock the conscience."

The primary purpose of the exclusionary rule is to protect individuals' constitutional rights to be free from illegal searches and seizures from governmental abuses. ${ }^{23}$ The rule does this through deterrence but not through personal compensation. In Elkins $v$ United States, ${ }^{25}$ the Court stated that the exclusionary rule is "calculated to prevent, not to repair., ${ }^{26}$ Later, in United States $v$ Calandra, the Court

20 See, for example, Wong Sun v United States, 371 US 471, 484 (1963). See also Nardone v United States, 308 US 338, 341 (1939) (coining the phrase).

21 See Weeks v United States, 232 US 383, 398 (1914) (holding that the state could not use the defendant's property as evidence in a trial against him where the police had violated the defendant's Fourth Amendment rights in obtaining the property).

22 See, for example, Gilbert v California, 388 US 263 (1967); Miranda v Arizona, 384 US 436 (1966); Mapp v Ohio, 367 US 463 (1961); Rochin v California, 342 US 165 (1952). See also Steven R. Schlesinger, Exclusionary Injustice: The Problem of Illegally Obtained Evidence 1-2 (Marcel Dekker 1977).

23 See Franks v Delaware, 438 US 154, 186 (1978); Weeks, 232 US at 398.

24 See United States $v$ Calandra, 414 US 338, 347-48 (1974) (stating that the purpose of the rule is to safeguard constitutional rights "generally through its deterrent effect, rather than a personal constitutional right of the party aggrieved").

25364 US 206 (1960).

26 Id at 217. The Supreme Court has additionally stated that a purpose behind the exclusionary rule is to promote judicial integrity. See, for example, Mapp, 367 US at 659 (stating that one of the considerations that led to the exclusionary rule was "the imperative of judicial integrity"), quoting Elkins, 364 US at 222. However, it has since assimilated this rationale to that of deterrence. See, for example, United States $v$ Leon, 468 US 897, 921 n 22 (1984) (explaining that the question of whether judicial integrity is threatened by false confessions "is essentially the same as the inquiry into whether exclusion would serve a deterrent purpose"), quoting United States v Janis, 428 US 433, 459 n 35 (1976).

27414 US 338 (1974). 
clarified that the purpose of the rule is to safeguard constitutional rights "generally through its deterrent effect, rather than [vindicate] a personal constitutional right of the party aggrieved. ${ }^{28}$ The primary way in which the exclusionary rule achieves this deterrence is through the "fruits of the poisonous tree" doctrine. Under this rule, any evidence that is obtained as a direct or indirect result of the use of the improper methods outlined above is excluded. The fruits of the poisonous tree doctrine is comparable to but-for causation analysis in tort law. There are, however, three categories of evidence that are not subject to the exclusionary rule. These exceptions to the rule are: where the link between the evidence and the illegal conduct is too attenuated, ${ }^{29}$ where evidence is gained from an independent source, ${ }^{30}$ or where evidence would have eventually been discovered through lawful means. ${ }^{31}$

If the "poisonous tree" is an improperly obtained confession, any information received because of that confession is excluded as "forbidden fruit." ${ }^{32}$ For example, when courts exclude statements made during unduly improper interrogations, any information obtained as a result of those statements are excluded, in addition to the ill-gotten statements themselves. ${ }^{33}$ However, where the improperly obtained

28 Id at 347-48.

29 See Nardone, 308 US at 341 (reviewing the connection between an illegal wiretap and other evidence in the government's case, finding that "[a]s a matter of good sense, [] such connection may have become so attenuated as to dissipate the taint"). But see Taylor v Alabama, 457 US 687, 693 (1982) (holding that fingerprints, themselves the fruit of an illegal arrest, "used to extract the confession from petitioner, cannot be deemed sufficient 'attenuation' to break the connection between the illegal arrest and the confession merely because they also formed the basis for an arrest warrant that was filed while petitioner was being interrogated").

30 See Segura v United States, 468 US 796, 799 (1984) (holding that evidence obtained as the result of an illegal entry need not be suppressed when a valid search warrant, relying on separate evidence, was issued the day after the initial seizure); Silverthorne Lumber Co $v$ United States, 251 US 385, 392 (1920) ("If knowledge of [certain facts] is gained from an independent source they may be proved like any others, but the knowledge gained by the Government's own wrong cannot be used by it.").

31 See Nix $v$ Williams, 467 US 431, 449-50 (1984) (holding that illegally obtained evidence relating to the body of a murdered victim was admissible because "the body inevitably would have been found" by search parties).

32 John Henry Wigmore, 3 Evidence in Trials at Common Law $\S 859$ at 555 (Little, Brown rev ed 1970) (James H. Chadbourn, ed) ("[I]t is realized [today] that the 'poisonous tree' doctrine may apply to confessions.").

33 See $N i x, 467$ US at 442 (noting that the fruits doctrine excluding evidence resulting from constitutional violations has been applied in cases of Fourth, Fifth, and Sixth Amendment violations). But see Michigan v Tucker, 417 US 433, 439 (1974) (holding that no constitutional violation resulted from the use of testimony of an alibi witness against defendant at trial where witness had been identified during interrogation undertaken without full Miranda warnings). The lower federal courts are split as to whether the fruits doctrine applies to physical evidence obtained from a Miranda violation. See United States $v$ Patane, 304 F3d 1013, 1019-29 (10th Cir 2002), cert granted, $123 \mathrm{~S} \mathrm{Ct} 1788$ (2003) (explaining the circuit split and holding that physical 
confession is a fabricated confession, there is no derivative information to exclude because the confession was made up by the police.

This gives rise to the major hole in the exclusionary rule about which this Comment is concerned: Since there are no "fruits" to be excluded in the event of a fabricated confession, the rule does not fulfill the goal of deterrence for which it was designed. The police may take the chance that they will not get caught fabricating a confession and that a court will believe that the fabricated confession was authentic. Even if they do get caught, the police do not lose much, since the only work they put into the fabricated confession was creating it, and the case against the defendant is not harmed beyond the exclusion of the confession. Consequently, the police may be under-deterred from fabricating confessions. ${ }^{34}$ The exclusionary rule is criticized for not deterring misconduct as much as a damages remedy would. ${ }^{35}$ If this is a valid criticism, then where the improperly obtained evidence is a police-fabricated confession, the under-deterrence problem is much worse.

The "poison from the poisonous tree" doctrine that I propose would actually deter the police officers from engaging in this behavior, as well as compensate victims for the harms they suffer during the criminal process. By holding an officer personally liable for all damages to the individual, a Section 1983 suit would compensate the victim and at the same time deter future misconduct. As in intentional torts, there should be no concern of over-deterrence-the optimal level of fabricated confessions is zero.

\section{SECTION 1983 LAW AND Police-FABRICATEd CONFESSIONS}

The use of a fabricated confession may violate constitutional rights, even if the suspect is not ultimately prosecuted. Police officers are not immune from Section 1983 claims for these harms. However,

evidence obtained from un-Mirandized statements must be suppressed, even if the statements are voluntary, because failure to give Miranda warnings is per se a Fifth Amendment violation).

34 This puts to the side the fact that most police officers are honest and have many moral reasons not to fabricate a confession. Although in most cases, native morality is a sufficient deterrent, the optimal level of fabricated confessions is zero. There is no risk of over-deterrence from the proposed "poisons" rule. There is also only a minimal risk that this rule would deter the police from engaging in legitimate police activity. This risk is discussed in Part III.E.2.

35 See Jeffrey Standen, The Exclusionary Rule and Damages: An Economic Comparison of Private Remedies for Unconstitutional Police Conduct, 2000 BYU L Rev 1443, 1446. See also Christopher Slobogin, Why Liberals Should Chuck the Exclusionary Rule, 1999 U III L Rev 363, 424 (stating that exclusion is "a way of restoring the parties to the status quo ante"). But see Irvine $v$ California, 347 US 128, 136-37 (1954) (stating that the goal of exclusion is deterrence and not compensation, and that it "protects one against whom incriminating evidence is discovered, but does nothing to protect innocent persons who are the victims of illegal but fruitless [activities]"). 
suspects must show that the fabricated confession is a but-for cause of the harm they suffered - that there actually is poison that flows from the poisonous tree.

\section{A. Standards for Section 1983 Claims}

Section 1983 provides a remedy to parties deprived of constitutional rights by a state actor acting under color of state law. ${ }^{36}$ To maintain a Section 1983 claim against a state official, such as a police officer, a plaintiff must establish that: (1) the alleged conduct was committed by an official acting within the scope of his authority; and (2) the conduct deprived the plaintiff of rights secured by federal law or the Constitution.

In enacting the statute, Congress meant to give a remedy to parties deprived of constitutional rights by an official's abuse of his position. ${ }^{38}$ Section 1983 "was intended to create 'a species of tort liability' in favor of persons who are deprived of 'rights, privileges, or immunities secured' to them by the Constitution.", Section 1983 damages both compensate the victim and deter misconduct. ${ }^{40}$

The Civil Rights Act has many limitations. Section 1983 does not provide a cause of action for every arrest or prosecution where the defendant is acquitted, because there is no constitutional guarantee that only the guilty will be arrested. ${ }^{41}$ However, a Section 1983 claim is

\section{See 42 USC $\$ 1983(2000)$ :}

Every person who, under color of any statute, ordinance, regulation, custom, or usage, of any State ... subjects, or causes to be subjected, any citizen of the United States ... to the deprivation of any rights, privileges, or immunities secured by the Constitution and laws, shall be liable to the party injured in an action at law, suit in equity, or other proper proceeding for redress.

\section{See Parratt $v$ Taylor, 451 US 527, 535 (1981):}

[I]n any $\S 1983$ action the initial inquiry must focus on whether the two essential elements to a $\S 1983$ action are present: (1) whether the conduct complained of was committed by a person acting under color of state law; and (2) whether this conduct deprived a person of rights, privileges, or immunities secured by the Constitution or laws of the United States.

See also Monroe v Pape, 365 US 167, 184 (1961) ("Misuse of power, possessed by virtue of state law and made possible only because the wrongdoer is clothed with the authority of state law, is action taken "under color of' state law."), quoting United States v Classic, 313 US 299, 326 (1941).

38 See Monroe, 365 US at 177-80 (reviewing legislative history of Section 1983 and evincing concern with disregard of citizens' constitutional rights by state officials).

39 Carey v Piphus, 435 US 247, 253 (1978), quoting Imbler v Pachtman, 424 US 409, 417 (1976).

40 See Richardson v McKnight, 521 US 399, 403 (1997) (stating that Section 1983 seeks "“to deter state actors from using the badge of their authority to deprive individuals of their federally guaranteed rights' and to provide related relief'), quoting Wyatt v Cole, 504 US 158, 161 (1992).

41 See Paul v Davis, 424 US 693, 701 (1976) (holding that Section 1983 does not provide "a right to be free of injury wherever the State may be characterized as the tortfeasor"); Smith $v$

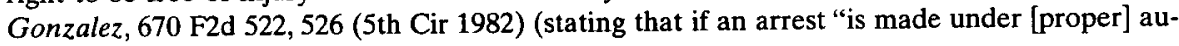


proper where the police fabricate a confession and use it in a criminal proceeding, because, in that case, a defendant's constitutional rights have been violated. ${ }^{2}$

As a form of tort liability, Section 1983 claims must be examined under the same set of rules that govern general tort law. ${ }^{43}$ This standard is designed "to implement the principle that a person should be compensated fairly for injuries caused by the violation of his legal rights." Thus, the claimant must establish four elements to maintain a Section 1983 claim: (1) a right enjoyed by the plaintiff under federal law or the Constitution is implicated; (2) the legal or Constitutional right has been violated; the violation was (3) the cause of (4) a harm to the plaintiff. The case law demonstrates that where the police fabricate a confession and it is used during the criminal process, a victim has a claim for relief under Section 1983 for harms they would not have suffered but for the fabrication.

The first case to raise a Section 1983 claim for a fabricated confession was Ricciuti $v$ NYC Transit Authority, ${ }^{45}$ in which the Caucasian defendant was arrested for fighting with an African-American man outside of Yankee Stadium. After the arrest, an officer included in the memo of the altercation a statement wherein Ricciuti allegedly used racially derogatory words while admitting to the fight. ${ }^{46}$ The supposed confession, however, was fabricated by the officer." Nonetheless, this statement led to a bias investigation and ultimately an added charge of a racially motivated crime, which involved more severe penalties. As a result, Ricciuti brought a Section 1983 action.

The Second Circuit denied summary judgment to the police officers and stated that when a police officer fabricates information that may influence a jury and forwards the information to prosecutors, "he violates the suspect's constitutional right to a fair trial." " Because of the constitutional violation, the fabrication was actionable under Section $1983 .{ }^{50}$ The court urged that if officers were able to fabricate con-

thority ... [the] arrest is not unconstitutional, and a complaint based on such an arrest is subject to dismissal for failure to state a claim").

42 See Part III.A.

43 See Memphis Community School District v Stachura, 477 US 299, 305-06 (1986).

44 Carey, 435 US at 257-58.

45124 F3d 123 (2d Cir 1997).

46 Id at 126

47 Id

48 Id at 126-27 (noting that, under New York law, a person is guilty of aggravated harassment when, "with intent to harass, annoy, threaten or alarm another person, he strikes ... another person ... or attempts or threatens to do the same because of the race ... of such person"), quoting NY Penal L $\$ 240.30(3)$ (McKinney 2002) (quotation marks omitted).

49 Ricciuti, 124 F3d at 130.

50 See id. 
fessions and forward them to the prosecutor, it would make a mockery of due process, and would "work[] an unacceptable 'corruption of the truth-seeking function of the trial process.",51 Thus, the court established that a fabricated confession could form the basis of a Section 1983 claim.

Perhaps more importantly, the court also addressed the scope of the claim. Even though Ricciuti's prosecution never went to trial, ${ }^{52}$ the Second Circuit held that the potential of the fabrication being used at trial deprived Ricciuti of his rights to a fair proceeding. Since the court extended the constitutional protection of a fair trial to a protection of the process leading up to a potential trial, it was able to conclude that the use of the fabrication in the investigation and indictment was actionable under Section 1983 . $^{\text {s. }}$

In addition to showing that the police violated a constitutional right, the aggrieved party must demonstrate that he was actually harmed by the officer's actions in fabricating the confession. ${ }^{5 s}$ Even if the plaintiff demonstrates the use of a false or partially false confession, if he is unable to show harms he may not recover under Section 1983.

In Stepp v Mangold, a police officer prepared a confession for Stepp to sign after he was arrested on robbery charges. ${ }^{57}$ Stepp signed the first two pages but refused to sign the others because "they referred to ... robberies other than the ones to which Stepp had confessed." additional robberies. However, there was no evidence that the unsigned confessions caused the initiation of the criminal prosecution, and there were independent reasons to arrest and prosecute him for

51 Id, quoting United States v Agurs, 427 US 97, 104 (1976).

52 Ricciuti, 124 F3d at 130.

53 See id.

54 In the subsequent trial, the jury rejected Ricciuti's factual claims and believed the police officers. See Ricciuti v NYC Transit Authority, 70 F Supp 2d 300, 332 (SD NY 1999). Furthermore, the court decided that even if the jury believed Ricciuti, the appropriate damages would have been nominal damages of $\$ 1$ because all charges were dropped (so there was no unfair trial), and his one night in jail would have happened anyway because there was independent authority for the arrest. See id. See also Part III.E.1. Although the fabrication constituted a constitutional violation, the plaintiff did not prove any actual damages. See Ricciuti, 70 F Supp 2d at 332. If, however, Ricciuti would have had to answer the additional charge in a criminal trial, or if he would have suffered additional harms because of the fabrication, then the damages certainly would have been different.

55 See Stepp v Mangold, 1998 US Dist LEXIS 8633, *20 (ED Pa) (granting summary judgment in favor of the police because Stepp failed to show that he was actually harmed).

561998 US Dist LEXIS 8633 (ED Pa).

57 Id at $* 2$.

58 Id. Furthermore, the officer did not change the written confession even after Stepp informed him of the error. 
those additional robberies. ${ }^{59}$ As a result, the court hearing Stepp's Section 1983 action granted summary judgment in favor of the police officer. Although the police fabricated a confession, it held that, but for the confession, Stepp's status would have been the same. ${ }^{60}$ Thus, the court found the police officer not liable, concluding the "[police] actions were reprehensible, but did not cause Stepp's erroneous conviction.",

Similarly, courts have held that where the criminal process would have continued in the same manner as it did, with or without the fabricated confession, the fabrication was not a but-for cause of the harms of the process. Therefore, there was no cognizable Section 1983 claim. For instance, in Hennick $v$ Bowling, ${ }^{62}$ the police allegedly included a fabricated confession in their police report. ${ }^{63}$ Although the charges against the defendant were ultimately dismissed, there were independent grounds for the arrest, and so there was no harm but for the fabrication. The court rejected the plaintiff's claims that the confession amounted to a constitutional violation, noting that there was probable cause independent of the confession to arrest the plaintiff. ${ }^{65}$ Any emotional or financial injuries suffered as a result of the arrest were not of a constitutional dimension because there was independent evidence and authority for that arrest. ${ }^{6}$

In its analysis, the district court in Hennick addressed the Ricciuti decision and stated that the Second Circuit was wrong in holding that the officer who fabricated confession was subject to a Section 1983 claim, because the deprivation of liberty in Ricciuti's case stemmed from circumstances independent of the confession. ${ }^{67}$ However, Hennick and Ricciuti can be reconciled without calling into question the logic of Ricciuti. These cases can be distinguished on the grounds that the fabricated confession in Ricciuti affected the criminal process (resulting in the higher charges), whereas the fabricated confession in Hennick did not change the defendant's status at all. In other words, but for the confession in Hennick, the defendant would have been in

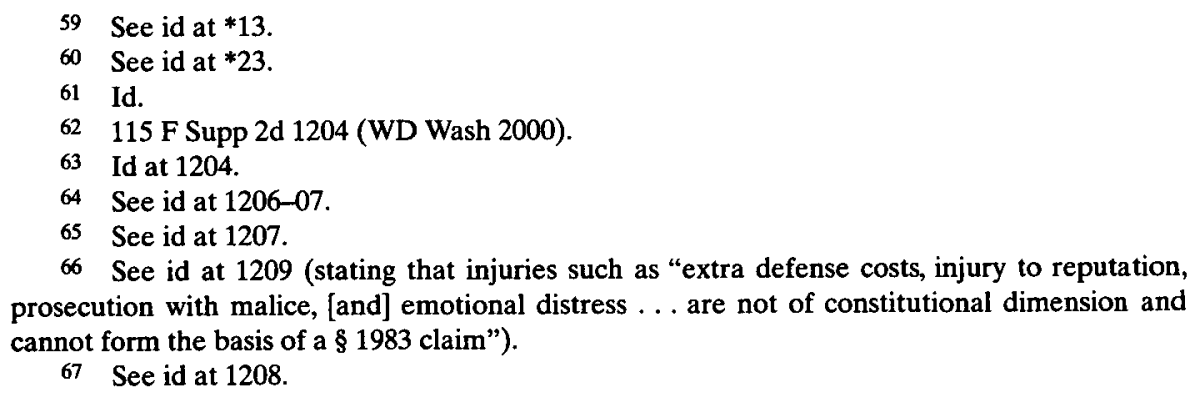


the same position; however, but for the confession in Ricciuti, the defendant would not have had to answer an additional charge.

\section{B. Section 1983 Immunities}

In addition to the requirements that the plaintiff show causation and harm, Section 1983 claims are limited by the availability of official immunities. There are two types of immunities potentially available to governmental officials: absolute and qualified. Absolute immunity is a status immunity that protects an official from any and all liability for actions taken within the scope of his official functions. ${ }^{68}$ Qualified immunity, on the other hand, shields officials from liability for discretionary acts only insofar as they do not violate clearly established constitutional rights. ${ }^{69}$ Neither immunity is available to police officers who fabricate confessions.

1. Absolute immunity in the fabricated confession context.

Absolute immunity from Section 1983 actions is the exception rather than the rule. It is available only to those actors who are "intimately associated with the judicial phase of the criminal process." ${ }^{70}$ This generally includes two classes of actors: witnesses, and judges and prosecutors in the performance of their duties."

For example, absolute immunity protects a prosecutor for her functions as an advocate, but not when she acts in an investigatory or administrative capacity. ${ }^{2}$ That is, immunity attaches to the office, not the person. Although police officers are not protected by absolute immunity in most of their functions, they are shielded from Section 1983 actions when they act as witnesses or otherwise provide testimony. ${ }^{3}$ This immunity is granted on the policy grounds that in order for officers to fully contribute to the judicial process, they must be afforded absolute immunity for their testimony. ${ }^{74}$ However, granting ab-

68 See, for example, Geter v Fortenberry, 849 F2d 1550, 1552 (5th Cir 1988).

69 See Harlow v Fitzgerald, 457 US 800, 818 (1982) (stating that qualified immunity protects conduct that "does not violate clearly established statutory or constitutional rights of which a reasonable person would have known").

70 Imbler, 424 US at 431 (holding that a state prosecutor had absolute immunity for the initiation and pursuit of a criminal prosecution, including the presentation of the case at trial).

71 See Briscoe v LaHue, 460 US 325, 335-36 (1983) ("[Section] 1983 does not authorize a damages claim ... against judges or prosecutors in the performance of their respective duties.").

72 See Buckley v Fitzsimmons, 509 US 259, 262-63 (1993) (holding that prosecutors were not absolutely immune for fabricating evidence because they were "performing essentially the same investigatory functions" as the police officers).

73 See id at 326.

74 See id at 343 ("Subjecting ... police officers to damages liability under $\$ 1983$ for their testimony might undermine ... their contribution to the judicial process [and] the effective per- 
solute immunity to officers who fabricate confessions would not further these interests. ${ }^{75}$ Consequently, the case law has shown that officers are not afforded absolute immunity for fabricating or testifying about manufactured evidence. ${ }^{76}$ An officer's conduct prior to testifying cannot "be immunized by later providing false testimony."

\section{Qualified immunity in the fabricated confession context.}

Unlike absolute immunity, which shields an individual from any suit, qualified immunity shields officials from liability only for those discretionary acts that do not violate clearly established constitutional norms. ${ }^{78}$ In Harlow v Fitzgerald, ${ }^{79}$ the Court set forth an objective standard for qualified immunity, requiring courts to determine whether a reasonable person would have known he was violating the plaintiff's constitutional rights. ${ }^{80}$ To show this, the plaintiff must demonstrate an actual violation of a constitutional or federal right about which the law was clearly established at the time of the violation. ${ }^{81}$ Thus qualified immunity does not shield police officers from liability for clear violations of the law of which a reasonable person would have been aware. ${ }^{82}$ In reaching these determinations, courts balance the need for police officers to perform their official duties without constant fear of litigation with a recognition that damages may be the only compensation for victims of constitutional violations.

formance of their other public duties.").

75 See Paine $v$ City of Lompoc, 265 F3d 975, 982 (9th Cir 2001) (explaining that the policy interests "that favor eliciting candid evidence at trial" do not comport with providing immunity for those who "tamper[] with documentary or physical evidence").

76 See, for example, Cunningham v Gates, 229 F3d 1271, 1291 (9th Cir 2000) ("[T]estimonial immunity does not encompass non-testimonial acts such as fabricating evidence."); Spurlock v Satterfield, 167 F3d 995, 1001 (6th Cir 1999) (refusing to grant defendant immunity for his testimony, which relied on evidence he manufactured).

77 Spurlock, 167 F3d at 1004 . Absolute witness immunity does not "relate backwards" to protect witnesses for illegal behavior undertaken before taking the witness stand. See Mastroianni v Bowers, $160 \mathrm{~F} 3 \mathrm{~d} 671,677$ (11th $\mathrm{Cir}$ 1998). Furthermore, commentators argue that "the funneling of fabricated evidence through a witness with absolute defamation immunity should not filter out liability for causing the continued incarceration of an innocent person." Douglas J. McNamara, Buckley, Imbler and Stare Decisis: The Present Predicament of Prosecutorial Immunity and an End to its Absolute Means, 59 Albany L Rev 1135, 1193 (1996).

78 See Malley $\vee$ Briggs, 475 US 335, 344 (1986) (stating that a standard of objective reasonableness defines the qualified immunity accorded an officer's request for a warrant); Harlow, 457 US at 806.

79457 US 800 (1982).

80 See id at 818 .

81 See id (stating that qualified immunity shields defendants "from liability for civil damages insofar as their conduct does not violate clearly established statutory or constitutional rights of which a reasonable person would have known").

82 See Malley, 475 US at 344.

83 See Spurlock, 167 F3d at 1005. 
Fabricating a confession or evidence is a clear constitutional violation if it is used during the criminal process, and hence officers who fabricate confessions are not protected by qualified immunity. ${ }^{84}$ The right not to have a fabricated confession used in a criminal proceeding is "sufficiently clear that a reasonable official would understand that what he is doing violates that right." case law, police officers are not entitled to qualified immunity for such conduct.

In Jones $v$ Cannon, ${ }^{86}$ for example, the Eleventh Circuit denied qualified immunity to the arresting officer for fabricating Jones's murder confession, and subsequently arresting Jones solely on the basis of the confession. ${ }^{87}$ The court stated that since the fabricated confession was the only probable cause for the warrantless arrest, and that no "reasonable police officer" would have thought there was probable cause to arrest Jones, the officer was not entitled to qualified immunity.

\section{The PoIson FROM the POISONOUS TREe Doctrine}

In this Part, I propose guidelines for how a court should evaluate a Section 1983 claim stemming from a police-fabricated confession. Under conventional tort-law analysis, the use of a fabricated confession would be the breach of a duty owed to the plaintiff, namely with respect to his Fourth or Fourteenth Amendment rights. Causation should be determined using a form of but-for causation, similar in its effect to the exclusionary rule. This, in turn, would entitle the plaintiff to damages for all harms that were the result of the deprivation of his rights.

\section{A. The Constitutional Right Implicated (Duty)}

A plaintiff must show an official duty to make out a Section 1983 claim. $^{89}$ It is clear that if the state obtains a conviction or makes an arrest as a result of the fabricated confession, the detainee's constitutional rights have been violated. ${ }^{30}$ However, there is disagreement over

84 See, for example, Buckley, 509 US at 276.

85 Anderson v Creighton, 483 US 635, 640 (1987).

86174 F3d 1271 (11th Cir 1999).

87 See id at $1283-84$.

88 See id.

89 See, for example, Nesses $v$ Shepard, 68 F3d 1003, 1005 (7th Cir 1995).

90 See Napue $v$ Illinois, 360 US 264, 269 (1959) (violation of due process right to a fair trial); Cannon, 174 F3d at 1283-84 (finding that using a fabricated confession as probable cause is a Fourteenth Amendment violation); Schneider v Estelle, 522 F2d 593, 595 (5th Cir 1977) (finding that manufacturing of evidence violated plaintiff's due process right to fair trial). 
whether bringing charges against a suspect on the basis of fabricated evidence is a constitutional violation in and of itself. ${ }^{91}$ Depending on the individual facts of a case, a plaintiff would most likely have either a Fourth Amendment claim for a pretrial deprivation of liberty, or a Fourteenth Amendment claim for a deprivation of his right to a fair trial. Furthermore, the plaintiff could state a claim that the presumption of innocence owed to him $^{92}$ was turned into a presumption of guilt due to the strength afforded a confession. Consequently, there are many potential federal rights that could be implicated depending on the facts of the case. What is clear, however, is that constitutional duties are implicated when a police officer fabricates a confession during the criminal process.

\section{B. The Use (Breach)}

In order for there to have been a constitutional violation, the fabricated confession must not only be manufactured, it must be used by the police in a criminal proceeding. ${ }^{93}$ In Zahrey $v$ Coffey, ${ }^{94}$ the Second Circuit stated that if the basis of a claim was only that the evidence was fabricated, and the existence of the false evidence "did nothing to precipitate the sequence of events that resulted in a deprivation of [] liberty," there would be no constitutional violation. ${ }^{95}$ For example, if an officer put the statement "in a drawer, or framed it and hung it on the wall but took no other step," there would be no violation." On the

91 Compare Devereaux v Abbey, 263 F3d 1070, 1074-75 (9th Cir 2001) ("[T]here is a clearly established right not to be subjected to criminal charges on the basis of false evidence."); Ricciuti, 124 F3d at 130, with Hennick, 115 F Supp 2d at 1208-09 (holding that since the plaintiff was not tried, "the most that can be said is that the false confession had the potential to, but did not, impinge on [the plaintiff's] rights," even though the fabricated confession led to police charging the plaintiff).

92 The presumption of innocence in favor of the accused is "undoubted" law; an "axiomatic and elementary" principle the enforcement of which "lies at the foundation of the administration of our criminal law." Coffin $v$ United States, 156 US 432, 453 (1895). See also Mahorney v Wallman, 917 F2d 469, 472 (1990) (stating that the presumption of innocence is "one of those basic rights whose violation may provide a ground for vacation").

93 See, for example Buckley v Fitzsimmons, 509 US 259, 281 (1993) (Scalia concurring) ("I am aware of no authority for the proposition that the mere preparation of false evidence, as opposed to its use in a fashion that deprives someone of a fair trial or otherwise harms him, violates the Constitution."); Zahrey v Coffey, 221 F3d 342, 348 (2d Cir 2000) (stating that manufacturing evidence does not in and of itself impair a constitutional right).

$94221 \mathrm{~F} 3 \mathrm{~d} 342$ (2d Cir 2000).

95 Id at 348.

96 Buckley $v$ Fitzsimmons, 20 F3d 789, 795 (7th Cir 1994), on remand from 509 US 259 (1993). The court further stated that "[o]btaining the confession ... does not violate any of [the plaintiff's] rights; using the confession could violate [the plaintiff's] rights." Id. 
other hand, fabricating a confession to a court or to a grand jury in a trial or probable cause hearing constitutes a use of the confession."

The "use" of the confession extends beyond presenting it at a trial or grand jury. For example, where an officer relies on a fabricated confession as probable cause for an arrest warrant, ${ }^{98}$ or gives it to a prosecutor as evidence," the confession is clearly "used." This use is a breach of the constitutional duties discussed in the previous Part. In sum, the action component of a constitutional violation is satisfied when the police-fabricated confession is employed during a criminal investigation or proceeding.

\section{But-For Causation}

Although tort law generally requires some theory of proximate cause to limit the tortfeasor's liability to that for which he is reasonably responsible, in analyzing Section 1983 actions for fabricated confessions, a but-for causation rule should be employed. This is essentially what the courts that heard these claims have collectively decided. Under this standard, a plaintiff must prove that the policefabricated confession was the but-for cause of the deprivation of his constitutional rights. ${ }^{100}$ The alternative, requiring proximate causation analysis, would cut off all liability in fabricated confession suits because, although the police launch a criminal investigation or proceeding, the prosecution brings the action. ${ }^{101}$ Consequently, under a proximate cause standard, an independent decision that is made by an intermediary, such as a prosecutor, judge, or grand jury, would break the causal chain, and insulate the police officer from legal responsibility. ${ }^{102}$ Under a but-for standard of causation, however, an intervening action would not break the causal chain if the police officer deceived, misdi-

97 See Whiting $v$ Traylor, 85 F3d 581, 585 n 5 (11th Cir 1996) ("Knowingly making false statements to obtain an arrest warrant" can be the basis for a claim.); McNamara, 59 Alb L Rev at 1992 (cited in note 77) ("Presenting altered or fabricated evidence to a grand jury or court is illegal. When false evidence impedes a fair trial, the defendant's constitutionally protected civil rights are violated.").

98 See Cannon, 174 F3d at 1283-84. See also Franks v Delaware, 438 US 154, 155-56 (1978).

99 See Ricciuti, 124 F3d at 130.

100 See, for example, Smith v Springer, 859 F2d 31, 34 (7th Cir 1988) (requiring the plaintiff to demonstrate that the fabricated evidence led to his false arrest and unreasonable seizure).

101 Reed $v$ City of Chicago, 77 F3d 1049, 1053 (7th Cir 1996) ("[The] State's Attorney, not the police, prosecutes a criminal action."); Eubanks v Gerwen, 40 F3d 1157, 1160 (11th Cir 1994) (noting that the police had nothing "to do with the decision whether or not to prosecute" the plaintiff).

102 See Smith $v$ Gonzalez, 670 F2d 522, 526 (5th Cir 1982) (stating that a presentation of a witness by a police officer to an attorney, who then issued an affidavit requesting a warrant, broke the causal chain and insulated the police officer from liability). 
rected, misled, or defrauded the intervening actor. ${ }^{103}$ The court in Jones $v$ Chicago $^{\text {104 }}$ used this standard:

[A] prosecutor's decision to charge, a grand jury's decision to indict, a prosecutor's decision not to drop charges but to proceed to trial-none of these decisions will shield a police officer who deliberately supplied misleading information that influenced the decision.... If police officers have been instrumental in the plaintiff's continued confinement or prosecution, they cannot escape liability by pointing to the decisions of [others] to confine or prosecute him. They cannot hide behind the officials whom they have defrauded.

When the police fabricate a confession, they are clearly defrauding, misleading, and deceiving everyone involved in the criminal process. Any decision made by a prosecutor, judge, grand jury, or jury will be tainted by the fabricated confession. Consequently, the standard used in the case law is essentially a but-for causation requirement, analogous to the "fruit of the poisonous tree" doctrine in the exclusionary rule. This analogy serves as a logical shortcut for courts to employ.

This suggested inquiry is the inverse of that undertaken by courts under the poisonous tree doctrine. ${ }^{106}$ Similar to tracing the fruit back to its initial impropriety, courts should ask what harms would not have resulted but for the police-fabricated confession. Just as all "fruit" obtained from the poisonous tree of an illegal search would be excluded, so should the victim of a police-fabricated confession be compensated for any and all "poison" that can be traced solely to the "poisonous tree."

103 See Robinson v Maruffi, 895 F2d 649, 655 (10th Cir 1990) (stating that the prosecutor, grand jury, and trial and appellate courts relied on the officer's falsified statements and therefore there was no break in causation); Hand v Gary, 838 F2d 1420,1427-28 (5th Cir 1988) ("Any misdirection of the magistrate or the grand jury ... perpetuates the taint of the original official behavior."). See also Barts v Joyner, 865 F2d 1187, 1195-96 (11th Cir 1989) (stating that intervening actors break the chain of causation unless "these intervening acts were the result of deception or undue pressure by the defendant policemen"). These cases are basically expanding the guidelines of proximate cause to but-for causation. By stating that intervening actors do not break the chain of causation, the courts are essentially framing the issue as: But for the officer's actions, would the defendant have suffered the harm in question?

104856 F2d 985 (7th Cir 1988).

105 Id at 994.

106 The inquiry in which a court engages for exclusionary rule purposes is "whether, granting establishment of the primary illegality, the evidence to which instant objection is made has been come at by the exploitation of that illegality or instead by means sufficiently distinguishable to be purged of the primary taint." Wong Sun v United States, 371 US 471, 488 (1963), quoting John M. Maguire, Evidence of Guilt: Restrictions upon Its Discovery or Compulsory Disclosure 221 (Little, Brown 1959). 
As discussed above, the greatest penalty, and thus compensation, available under the exclusionary rule is the exclusion of highly probative evidence. ${ }^{107}$ Since "damages are based on harm" and "exclusion on gain," ${ }^{, 10}$ in situations where there is only harm, as in fabricated confession cases, damages provide both the sole remedy and the sole punishment for police who engage in this activity. This level of deterrence is needed because confessions are so potent in their effect. Furthermore, as previously mentioned, the exclusionary rule does not effectively deter this conduct, nor does native morality.

The but-for test is appropriate because the link in the causation chain is not broken by any independent authority, so long as the authority relies on the fabricated confession. This piece of "evidence" will consequently harm the criminal defendant from the time it is initially used until it is eventually discovered as having been fabricated. A proximate cause analysis would not recognize that the entire process is altered because of a fabricated confession.

\section{Harms to Redress}

Any appearance of a fabricated confession at trial denies the criminal defendant a fair trial. ${ }^{109}$ This is clearly a harm that can be redressed under Section 1983. ${ }^{1.0}$ Further, since confessions are so potentially damaging, any use of a fabricated confession in the criminal process potentially deprives defendants of a fair proceeding. ${ }^{111}$ To hold otherwise "would make a mockery of the notion that Americans enjoy the protection of due process of the law and fundamental justice."112

In addition, the fabricated confession harms the criminal defendant long before the trial. In the criminal justice system, "the most significant sanctions [on the criminal defendant] often are: (1) the arrest itself; (2) the search incident to arrest which may enable the police to charge the suspect with a[n] [ ] offense; and (3) the period spent in jail before the suspect appears in court." ${ }^{113}$ The fabricated confession changes the entire way the criminal process treats the defendant. ${ }^{114}$ In the words of Malcolm Feeley's classic title, "The Process Is the Pun-

107 See Standen, 2000 BYU L Rev at 1456 (cited in note 35).

108 Id at 1487.

109 See Ricciuti, 124 F3d at 130.

110 See id.

111 See Wrightsman and Kassin, Confessions in the Courtroom at 36 (cited in note 3). See also text accompanying notes $2-10$.

112 Ricciuti, 124 F3d at 130.

113 Albert W. Alschuler and Stephen J. Schulhofer, Antiquated Procedures or Bedrock Rights?: A Response to Professors Meares and Kahan, 1998 U Chi Legal F 215, 236.

114 See notes 11-13 and accompanying text. 
ishment." "115 This wrongful "punishment" is the harm for which the criminal defendant should be compensated under a Section 1983 claim.

\section{E. Limitations on the "Poison from the Poisonous Tree" Rule}

Similar to the exclusionary rule, the proposed "poison" doctrine would have three limiting principles. These consequences and exceptions balance the police interests of arresting criminals and gaining evidence for prosecution with the interests of innocent defendants in not having a fabricated confession used against them at any point of the criminal process.

1. Independent grounds for prosecution.

A natural result of the but-for causation rule is that criminal defendants are not compensated when they would have suffered the same harms with or without the fabricated confession. The "fruits" doctrine of the exclusionary rule recognizes that knowledge obtained through improper means is admissible if it was also gained from an independent, proper source. ${ }^{116}$ Similarly, if, without the fabricated confession, the evidence would support the actions taken against the criminal defendant - such as an arrest, warrant, or prosecution - then the fabricated confession could be said to have no impact. ${ }^{117}$ It follows that a check on the test of whether the "poison" came from the fabricated confession should be the additional inquiry of whether the "real" evidence was sufficient, on its own, for the criminal proceeding or investigation to proceed without the fabricated confession. ${ }^{118}$ If other evidence is sufficient, there is no but-for causation, and hence the officer should not be held liable under Section 1983.

The fabricated confession cases discussed in Part II follow this rule. In Hennick and Stepp, where the Section 1983 claims could not proceed, there were independent grounds upon which to arrest, and initiate prosecution against, the suspect. In contrast, in Ricciuti and

115 Malcolm M. Feeley, The Process is the Punishment (Russell Sage Foundation 1979).

116 See Silverthorne Lumber Co v United States, 251 US 385, 392 (1920) ("If knowledge of [facts] is gained from an independent source they may be proved like any others, but the knowledge gained by the Government's own wrong cannot be used by it.").

117 See Franks, 438 US at 155-56 (false statement must be necessary to the finding of probable cause).

118 See, for example, id (holding that a search warrant obtained with false information will not be voided when independent grounds existed for granting it); Tomer $v$ Gates, 811 F2d 1240, 1242 (9th Cir 1987) (holding that since the search warrant was not exclusively based on the fabricated evidence, there was no causation). But see Cervantes v Jones, 23 F Supp 2d 885, 88-89 (ND Ill 1998) (stating that the standard is whether the alleged fabrications played a "significant role" in causing a prosecution). 
Jones, where the suits were allowed to proceed, the courts held that there was no other authority that would have served as probable cause for an arrest, or led a prosecutor to add charges.

\section{Legitimate police practices.}

The goal behind this rule is not to deter legitimate police activity or to restrain officers from adequately performing their job. Consequently, legitimate practices that involve deception are an exception to the but-for rule. For example, this would apply in situations when police fabricate an accused's (Prisoner A) confession as a trick to obtain a real confession from Prisoner A's accomplice, Prisoner B. The real confessions that arise from this form of police trickery are usually, and should be, admissible at trial. ${ }^{119}$ The situation might occur as follows: The police tell B that A has confessed. In fact, A has not confessed and so A's "confession" is fabricated. Based on this knowledge, $B$ then actually does confess and provides evidence that is harmful to A. But for the fabricated confession, B would not have confessed, and there would not be the added evidence against A. Although this would satisfy the but-for causation requirement of the "poison from the poisonous tree" doctrine, this "legitimate police practice" should not lead to a Section 1983 claim. This exception should be made because it would run counter to the judicial process if a police act were allowed during a criminal trial, but then held to be improper in a civil trial.

3. Favorable termination of the criminal proceeding.

A final limitation is that in order to state a Section 1983 claim for harms that stem from a police-fabricated confession, a plaintiff must demonstrate that the criminal trial terminated favorably to the suspect. ${ }^{120}$ Favorable terminations include: acquittal, dismissal, reversal, expungement by executive order or judicial expungement, a federal court's issuance of a writ of habeas corpus, and executive pardons. ${ }^{121}$

119 See, for example, Brandon v LaVallee, 391 F Supp 1150, 1151-52 (SD NY 1974) (upholding a conviction, based in part on a confession that was obtained through the prisoners' dilemma); State v Palko, 121 Conn 669, 186 A 657, 661-62 (1936) (same); Osborn v People, 83 Colo 4, 262 P 892, 902 (1927) (same). But see Robinson v Smith, 451 F Supp 1278, 1292-93 (WD NY 1978) (holding that a confession could be suppressed where police told the defendant that an accomplice had accused him of shooting the victim of a robbery during the accomplice's confession).

120 See Heck v Humphrey, 512 US 477, 484 (1994).

121 See, for example, id at 486-87; Snyder v City of Alexandria, 870 F Supp 672, 686 n 37 (ED Va 1994). 
This requirement is in place to prevent a convicted criminal from collaterally attacking a conviction through a civil suit. ${ }^{122}$ Otherwise, a defendant would be permitted to relitigate the issues that he lost in the criminal trial. ${ }^{123}$ Furthermore, even if the defendant proved in the criminal trial that the confession was fabricated, there would obviously be some independent authority that resulted in his incarceration.

\section{CONCLUSION}

Although the exclusionary rule is designed to deter police misconduct, it offers no remedy or compensation to victims of policefabricated confessions. The law, however, recognizes the tremendous impact that a confession can have on a criminal investigation, proceeding, or trial.

Insofar as a fabricated confession is used during any phase of a criminal proceeding, the confession potentially violates a suspect's constitutional rights. Consequently, once the suspect's criminal proceeding terminates favorably, he can bring a Section 1983 claim against the police officer who fabricated the confession. Neither absolute nor qualified immunity can shield the officer from such a suit. The plaintiff should be compensated for any harms that have their roots in the use of the fabricated confession under a but-for causation standard. The limits to this "poison from the poisonous tree" doctrine balance the needs of the police with the goal of compensating victims for, and deterring officers from, wrongful conduct.

122 See Heck, 512 US at 486 ("[T] he hoary principle that civil tort actions are not appropriate vehicles for challenging the validity of outstanding criminal judgments applies to $\S 1983$ damages actions that necessarily require the plaintiff to prove the unlawfulness of his conviction or confinement.").

123 See Singleton $v$ City of New York, 632 F2d 185, 195 (2d Cir 1980) (noting that to allow otherwise would "pos[e] the prospect of harassment, waste and endless litigation, contrary to principles of federalism"). 


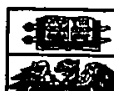
$\left(\begin{array}{r}1 \\ +3\end{array}\right)$ 